\title{
操作入力と環境認識に基づく操作性の低いデバイスを利用する知 的車いすの行動制御
}

\author{
石 原 悠*1 高 橋 正 樹*2

\begin{abstract}
Action Control based on Input Commands and Environment Recognition for Smart Wheelchairs Controlled by Low Operability Devices
\end{abstract}

Yu Ishihara*1 and Masaki Takahashi*2

\begin{abstract}
Powered wheelchair is a mobility commonly used for people with disabilities. Recently, to improve the safety and efficiency of powered wheelchairs, various systems with control assistance are proposed. However most of the systems suppose joystick as input device and doesn' t consider about people with difficulties using it. Not all devices alternative to joystick have enough operability compared to joystick. In this paper, considering corridor passing as verification environment, an action control method to drive through the corridor safely and efficiently for wheelchairs controlled by devices with low operability is presented. To achieve safe and efficient driving, proposed method considers the passenger's input commands and combines the environmental information to select effective direction and speed for the wheelchair instead of passenger. Moreover for environment recognition, corridor detection algorithm is also proposed. To verify the effectiveness of proposed method, several simulations and experiments were carried out.
\end{abstract}

Key Words: Smart Wheelchair, Man-Machine Interaction, Corridor Detection, Action Control

\section{1. 緒言}

近年の高齢化などに伴い, 車いすの需要が増加している [1] [2]. 現在市販されている車いすは，移動に際し，操作や安全の確認 を搭乗者が自ら行わなければならないが，車いす利用者の $61 \%$ 以上は, 十分な操作や安全の確認を行うことが困難であるため, 障害物回避機能などのアシスト機能を搭載した車いすが必要で あると言われている $[2]$. そのような背景から，機械側が搭乗者 をアシストすることにより, 安全で効率的な移動を可能にする研 究が広く行われてきた $[3] 〜[6] . 儿$ しい, それらの多くは, ジョ イスティックによって操作することを前提として扔り，上半身 が不自由であるなど, ジョイスティックを扱うことが困難であ る人は想定してこなかった．ジョイステイックに代わるデバイ スである, 音声認識や顔認識, ブレインマシンインタフェース (Brain Machine Interface: BMI) などを扱い，車いすを動か す研究も複数行われているが $[7] \sim[11]$, 従来は主に, デバイス を利用していかに車いすを動かすかに焦点が当てられ，これら が一般的にもつ, 入力方向が少ない, 動作周波数が低いといっ た特徴を陽に考慮していない，そのため，移動に際して搭乗者

原 2011 年 11 月 9 日

$* 1$ 慶應義塾大学大学院理工学研究科

$* 2$ 慶應義塾大学理工学部

${ }^{* 1}$ Graduate School of Science and Technology, Keio University

${ }^{* 2}$ Faculty of Science and Technology, Keio University

ロ本論文は提案性で評価されました。
が複雑な入力を行い，車いすの方向を微調整したり，方向転換 の度に車いすを停止させたりする必要があるなど, 必ずしも効 率的に移動が行えているとは言えず, 操作時の搭乗者の負担が 大きいという問題があった。

これまでに，操作性の低いデバイスを利用する車いすのアシ スト手法としては, 自動走行 [9] と, リアクテイブな障害物回 避手法を適用するもの [7] [12] の二つのアプローチがある. 前者 は, 搭乗者が直接車いすを操作する必要がないことから, 操作 性の低さはあまり問題とならないが, あらかじめ環境地図など の事前情報を必要とするため, 事前に情報が得られない地点に は移動できず，行動範囲に制限がある，後者は，障害物回避機 能により安全に移動できるが, 前述したように, デバイスの操 作性の低さを補っては招らず，効率的な移動が実現できていな い. そのため, 操作性の低いデバイスを用いる車いすの安全で 効率的な移動には, デバイスの操作性を補い, かつ, 環境地図 を必要とせずアシスト可能なシステムを構築する必要があると 考えられる. 本研究では, このような操作性の低いデバイスを 利用する車いすの安全で効率的な移動の実現を目的とする。

車いすが環境地図を持たずアシストを行うためには，各時刻 に扔いて直進や右左折, 障害物回避といった, 搭乗者の行動意 図を知り，センサ情報を基にリアクティブに行動を生成する必 要がある. しかしながら, デバイスの操作性が低い場合, デバイ スからの入力のみでは, どの方向を搭乗者が目指し, 何を目的 として入力を行ったのか不明瞭であるため, 適切なアシストを 


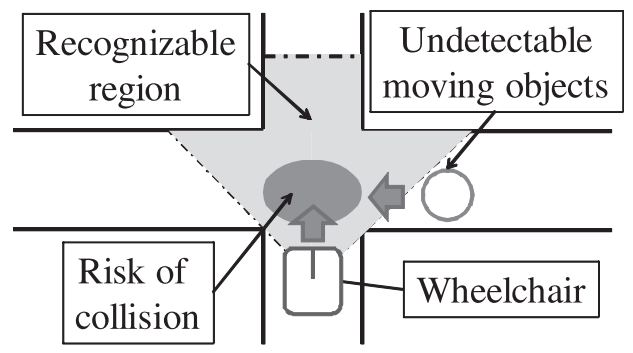

Fig. 1 Situation which deceleration is needed

行うことが難しい. すなわち, 入力方向の少なさや低い動作周 波数, といったデバイスの有する問題点を他のセンサ情報など を利用し, 補完しなくてはならない. 解決法の一つとして, 顔 の向きを利用する方法が提案されているが $[11]$, このように特 定の動きを要求することは負担であり望ましくない。 また，車 いす利用者は, 必ずしもそのような運動が可能とは限らない.

そこで本研究では, 壁や人などの障害物を認識し, その回避 を行うだけでなく，車いす周囲の通路認識を行い，デバイスか ら得られる入力情報に加えて，通路の位置情報を利用すること で搭乗者の行動意図を推定する。そして，推定した行動意図や 環境に応じた速度指令を決定し, 安全で効率的な移動を可能に する車いすの行動制御手法を提案する. 本研究では, 数值シミュ レーションと市販の電動車いすを利用した実験により, 提案手 法の有効性を次の二点から検証する.

(a)十字路進入時および方向転換時の車いすの自動的な速度と 角速度の調整

(b) 滑らかで効率的な通路の右左折

（a）は速度や角速度の調整をせずに移動した場合，右左折する ための入力を行う時間を十分確保できず，方向転換に失敗する 場合がある. 加えて, 十字路に進入した際, Fig. 1 のようにセ ンサで検知できない動的な障害物と接触する危険性を下げるた めである。一方，（b）は方向転換のたびに停止する必要をなく し，効率的な移動を実現するためである.

\section{2. 車いすの制御システム}

Fig. 2 に提案する制御システムの概略図を示す。本制御シス テムは操作入力と環境の認識結果を同時に考慮し, 速度指令を 決定する. その特徵は, ある時刻において同じ入力を搭乗者が 行っても, 環境の状態だけでなく, 入力に応じて車いすへの出 力が変化する点および周囲の通路の位置を行動決定時に利用す る点である. 次節以降, 本制御システムにおける, 通路検出手 法, 目標速度と目標角速度の設定方法および障害物回避手法に ついて述べる。具体的な行動制御系の設計法については 3 章で 述べる。本研究では, 入力方向が「前」,「右」,「左」の三方向 を与えることができ，その動作周波数が $2.0[\mathrm{~Hz}]$ であるような 非侵襲型の BMI を用いて操作する車いすを仮定する [10] [13].

また，センサとして，前方を $0[\mathrm{deg}]$ とし， $\pm 120[\mathrm{deg}]$ の範 囲で最大 $4.0[\mathrm{~m}]$ まで周囲の物体との距離を測定できるレーザ レンジファインダ (Laser Range Finder: LRF) が搭載されて いる 2 輪駆動の電動車いすを制御対象として想定する.

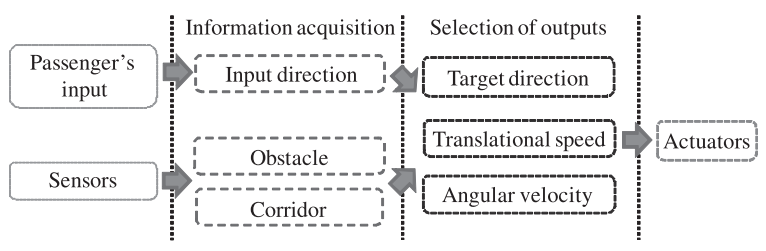

Fig. 2 Overview of proposed assist facility system

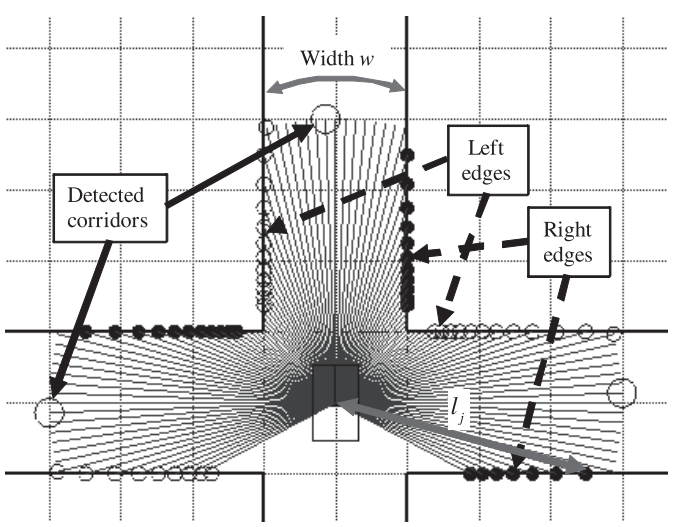

Fig. 3 Corridor detection $\left(e_{t h}=0.07[\mathrm{~m}], w_{t h}=0.30[\mathrm{~m}]\right)$

\section{1 通路検出}

提案する通路検出手法について説明する。 ここで通路は, 二 つの平行な直線で表現できるものとする，まず，通路の候補を 抽出するため, 次式を用いて Fig. 3 に示すような, 壁の端（本 論文では以下，エッジ）を検出する。

$$
\left|l_{i}-l_{i-1}\right|>e_{t h}
$$

ここで, $l_{i}$ は LRF の $i$ 番めの距離データであり, $e_{t h}$ はエッ ジ検出のための闇值である。すなわち，式（1）を満たす場合， $i$ 番めのデータをエッジとみなす。このとき, $l_{i}-l_{i-1}$ の正負 に応じて，Fig. 3 に示すように，右側と左側に対応するエッジ を区別する。ここではデータの番号付けを反時計回りに行って いるため, $l_{i}-l_{i-1}$ が正のときは右側, 負のときは左側と認識 する.

次に，右側から左側にエッジが切り替わる箇所の，エッジ間 の円弧の長さ $w_{j}$ を次式で計算する.

$$
w_{j}=l_{j} \times r_{r e s} \times d_{e d g e}
$$

式 $(2)$ 中の $l_{j}$ は車いすと右側のエッジの距離, $r_{r e s}$ は 1 スキャ ンあたりの LRF の角度分解能, $d_{\text {edge }}$ は右側と左側のエッジのス キャン番号の差である. そして, 閾值 $w_{t h}$ を用いて, $w_{j} \geq w_{t h}$ であればそれを通路として検出し, 右側と左側のエッジの中点 方向を通路方向 $\varphi_{C}$ とする。本研究では予備実験に基づき, $e_{t h}$ を $0.07[\mathrm{~m}], w_{t h}$ を $0.30[\mathrm{~m}]$ とした。これは幅 $2.0[\mathrm{~m}]$ の通路 を, 十字路の中心より手前 $2.0[\mathrm{~m}]$ 地点から検出するための值 である。

さらに本論文では, 上記の提案手法に加え, より正確に通路 の位置を検出するため, 文献 [14] を参考にした, 通路検出アル ゴリズムも併用した，具体的には，位置の正確性は劣るが検出 率の高い提案手法により, 通路候補を検出する一方, 文献 [14] 


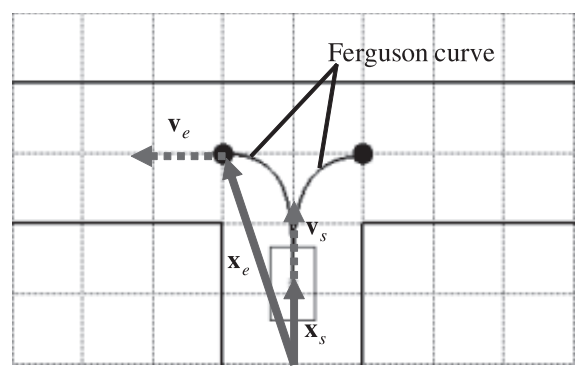

Fig. 4 Example of Ferguson curve

を基にしたアルゴリズムで，通路の位置が正確に導出できた場 合は，そちらを優先して利用するといった方法をとった．

\section{2 目標速度および目標角速度の設定}

操作入力と通路認識結果に基づき, 目標速度と目標角速度を 設定する.

初めに，目標速度の決定法について述べる。まず，車いすと 前節で検出した各通路を結ぶ, Fig. 4 に示すような曲線を計算 する. Fig. 4 の曲線は, 次式のファーガソン曲線 [15] である.

$$
\begin{aligned}
\mathbf{x}_{c}(t) & =\left[\begin{array}{lll}
x_{c}(k) & y_{c}(k)
\end{array}\right] \\
& =\left[\begin{array}{cccc}
k^{3} & k^{2} & k & 1
\end{array}\right] \mathbf{A B}\left[\begin{array}{l}
\mathbf{x}_{s} \\
\mathbf{x}_{e} \\
\mathbf{v}_{s} \\
\mathbf{v}_{e}
\end{array}\right] \\
\mathbf{A} & =\left[\begin{array}{cccc}
2 & -2 & 1 & 1 \\
-3 & 3 & -2 & -1 \\
0 & 0 & 1 & 0 \\
1 & 0 & 0 & 0
\end{array}\right] \\
\mathbf{B} & =\left[\begin{array}{cccc}
1 & 0 & 0 & 0 \\
0 & 1 & 0 & 0 \\
0 & 0 & \alpha & 0 \\
0 & 0 & 0 & \beta
\end{array}\right]
\end{aligned}
$$

$\alpha$ および $\beta$ は係数であり，本論文ではいずれも試行錯誤的に 3 とした. また, 式（3）に拈ける $k$ は 0 以上 1 以下の媒介変数, $\mathbf{x}_{s}, \mathbf{x}_{e}$ はそれぞれロボット現在地および通路の位置べクトル, $\mathbf{v}_{s}$ は, ロボットの速度ベクトルを正規化し, 大きさ 1 としたべ クトル, $\mathbf{v}_{e}$ は, 同様に大きさ 1 で通路方向のベクトルとする. これらのベクトルはすべて，車いすに固定された座標系を基準 として計算する。本論文では, この曲線の曲率半径から, 通路 方向へ向かう場合に, どの程度旋回する必要があるかを評価し, 行きすぎや急激な駆動とならないよう, 車いすの並進速度の最 大值 $v_{\max }$ を調整する。ここでは, 曲線を追従するように車い すを制御するのではないことに注意されたい. $m$ 番めの通路と 車いすを結ぶ曲線の曲率半径の最小值 $r^{m}$ は次式で求められる。

$$
r^{m}=\min _{k}\left|\frac{\left(\left(\frac{d^{2} x_{c}}{d k^{2}}\right)^{2}+\left(\frac{d^{2} y_{c}}{d k^{2}}\right)^{2}\right)^{3 / 2}}{\frac{d x_{c}}{d k} \frac{d^{2} y_{c}}{d k^{2}}-\frac{d^{2} x_{c}}{d k^{2}} \frac{d y_{c}}{d k}}\right|
$$

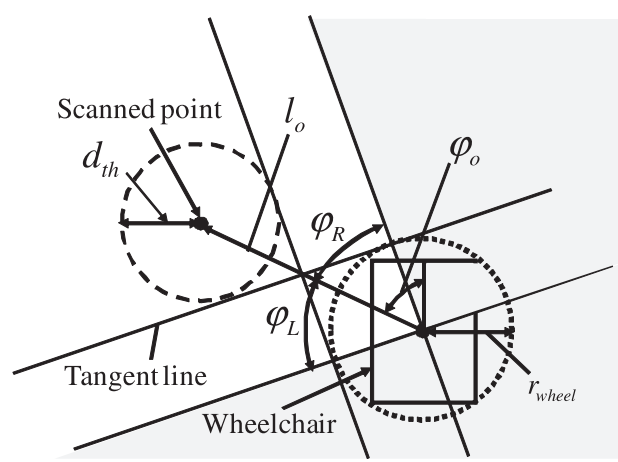

Fig. 5 Region for avoiding obstacle

以上を用いて，検出された $m$ 番めの通路に対する速度の最大 值 $v_{\max }^{m}$ を次式で算出する。

$$
v_{\max }^{m}=\min \left(\sqrt{a_{\max } r^{m}}, v_{\text {wheel }}\right)
$$

$a_{\max }$ は車いすの旋回中心方向の加速度の最大值であり, ISO [16] で規格化されている人間が不快に感じにくいとされる加速度の 範囲を参考に，本論文では $a_{\max }=0.3\left[\mathrm{~m} / \mathrm{s}^{2}\right]$ とした。 $v_{\text {wheel }}$ は車いすが物理的に出すことが可能な最大速度である。本論文 では $v_{w h e e l}=0.75[\mathrm{~m} / \mathrm{s}]$ とした. すなわち， $v_{\max }^{m}$ は旋回中心 方向の加速度が， $a_{\text {max }}$ を超えずに，曲線上を移動可能な速度と なる. これより, 並進速度の最大值 $v_{\max }$ を次式で求める.

$$
v_{\max }=\max \left(\min _{m} v_{\max }^{m}, v_{\max }^{\prime}\right)
$$

$v_{\max }^{\prime}$ は，車いすが右左折しないにもかかわらず停止してしま い，移動できなくなることを防ぐための速度制限值の下限であ る. 本論文では, $0.25[\mathrm{~m} / \mathrm{s}]$ に設定した.

次に目標方向について述べる. 目標方向は, 操作入力が左で あり，左側に通路が検出されていれば，検出された左側の通路 を目標方向に, 通路がない場合は目標方向を $25[\mathrm{deg}]$ に設定す る. 操作入力が右の場合はその逆である. それ以外の場合は直 進するように目標方向を定める. 最後に回転角速度は, 前方に 通路が検出されている場合は, 最大值 $\omega_{\max }$ を $15[\mathrm{deg} / \mathrm{s}]$ にす る.これは, 回転中に前方に通路が発見された場合, 回転を遅 くすることにより, 入力を待ち, 前方に進むのか, さらに回転 を行い, 別の通路を目指すのか判断するためである. それ以外 の場合， $\omega_{\max }$ を $45[\mathrm{deg} / \mathrm{s}]$ にする.

\section{3 障害物回避}

車いすが障害物と接触しないようにするため, 相対的な位置 関係に基づき, LRF の各観測点に対し，Fig. 5 に示す死色で示 す領域を計算する。各観測点に対して上記の領域を計算するた め, 任意形状の障害物を回避することが可能である. Fig. 5 に 示す灰色で示す領域は, 車いすに外接する半径 $r_{w h e e l}$ の円に 対し, その中心が移動した場合に, 観測点と距離 $d_{t h}$ 以上を保 ちながら移動可能な領域を表す。具体的には, 次式で計算され る, 方向 $\varphi_{R}$ と $\varphi_{L}$ の外側を車いすが移動するように制御を行 い, 障害物を回避する。ここで次式の $l_{o}$ は，車いすと観測点と の距離である,

$$
\varphi_{R}=\varphi_{L}=\arcsin \left(\left(r_{w h e e l}+d_{t h}\right) / l_{o}\right)
$$




\section{3. ファジィポテンシャル法に基づく行動制御系の設計}

2 章で述べたシステムの実現には, 目標方向への移動や障害物 回避などの様々な要求を考慮し, 車いすの制御を行う必要があ る. 本研究では, 提案するシステムのリアクテイブな行動制御手 法に基づく設計の一例として, 複数の要求を同時に考慮すること が可能な, ファジィポテンシャル法 (Fuzzy Potential Method: FPM） [17] に基づく行動制御の設計法を提示する．FPM は目 標方向への移動や障害物回避といった, 各基本行動を表現する, 横軸が車いす正面からの相対角度, 縦軸がその角度に対する優 先度を表すポテンシャルメンバーシップ関数（Potential Membership Function: PMF）を作成し，それらをファジィ演算で 統合することにより, 各基本行動の要求を考慮して目標速度指 令を決定する手法である，以下に，PMF の設計法㧍よび車い すの速度指令值の算出法を述べる.

\section{1 目標方向に進むための $\mathrm{PMF}$}

車いすを目標方向に移動させるため, Fig. 6 に示す三角形の PMF $\mu_{d}$ を作成する. Fig. 6 の方向は反時計回りを正とし, 車 いす前方を $0[\mathrm{deg}]$ としている. 頂点の位置 $\varphi_{d}$ は， 2.3 節で述 べた目標方向であり, 直進時は $0[\mathrm{deg}]$, 右左折時は $\pm 25[\mathrm{deg}]$ もしくは検出した通路方向 $\varphi_{c}$ となる。 しかし, Fig. 7 のよう に, 壁とそのマージン $d_{t h}$ を考慮した場合に, 通路方向への直 接の進行が阻まれてしまう場合は, Fig. 7 に示す $\varphi_{c}^{\prime}$ を目標方 向とする。 これは, 壁とそのマージンに進行が阻まれない方向 の中で， $\varphi_{c}$ に最も近い方向，すなわちマージンに接する方向で ある. $d_{t h}=0[\mathrm{~m}]$ の場合, $\varphi_{c}^{\prime}$ は $\varphi_{c}$ に一致する. グレードの 最大值は常に 1.0 となるように設計する.

\section{2 障害物を回避するための $\mathbf{P M F}$}

障害物を回避するため, Fig. 5 に示した $\varphi_{R}$ と $\varphi_{L}$ を用いて, Fig. 8 に示すような凹型の PMF $\mu_{o}^{n}$ を作成する. 添え字 $n$ は, $n$ 番めの障害物に対する PMF であることを表す。この $\mathrm{PMF}$ $\mu_{o}^{n}$ のグレード $a$ は次式より算出する. ここで $l_{o}<l_{t h}$ のとき, $a$ を 0 とせず, 次式で求めるのは, FPM ではグレードの值で 速度が決まるため, 急減速しないようにするためである. 式中 の $l_{t h}$ は, 障害物を回避し始める距離である.

$$
a=\left\{\begin{array}{l}
\frac{\left(l_{o}-d_{t h}-r_{w h e e l}\right)}{\left(l_{t h}-d_{t h}-r_{w h e e l}\right)} \quad \text { if } l_{o}<l_{t h} \\
1.0 \quad \text { otherwise }
\end{array}\right.
$$

そして, 全 $N$ 個の障害物に対する PMF の論理積をとること で，周囲の障害物を回避するための $\mathrm{PMF} \mu_{o}$ を得る.

$$
\mu_{o}=\mu_{o}^{1} \wedge \cdots \wedge \mu_{o}^{N}
$$

\section{3 指令值の決定}

PMF を統合し, 各要求を考慮した速さ $v_{\text {out }}$ と角速度 $\omega_{\text {out }}$ を算出する，まず, PMF $\mu_{d}$ と $\mu_{o}$ の代数積をとり, PMF を 統合する.

$$
\mu_{\text {mix }}=\mu_{d} \cdot \mu_{o}
$$

次に, 車いすの進行方向 $\varphi_{\text {out }}$ と速さ $v_{\text {out }}$ を, 式 (10) で統合 したPMF と 2.2 節の式（6）で算出した $v_{\text {max }}$ を基に次式で計 算する。

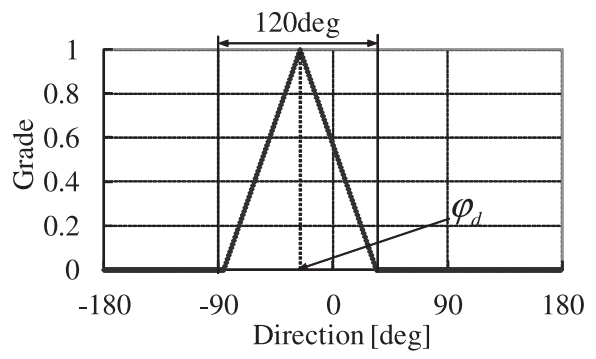

Fig. 6 Example of PMF $\mu_{d}$

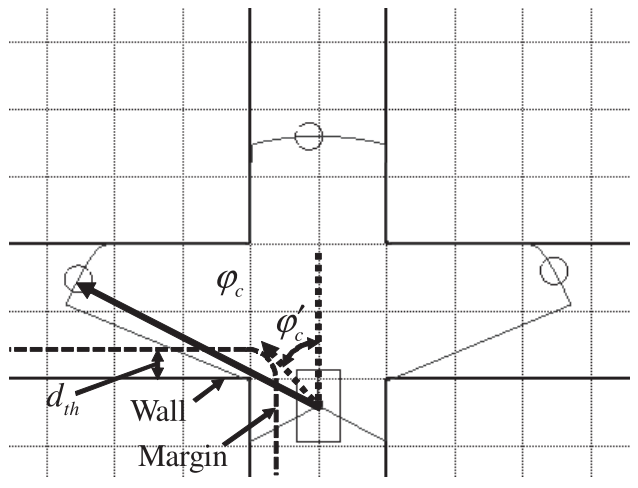

Fig. 7 Example situation which the driving of wheelchair is blocked by the wall and its margin

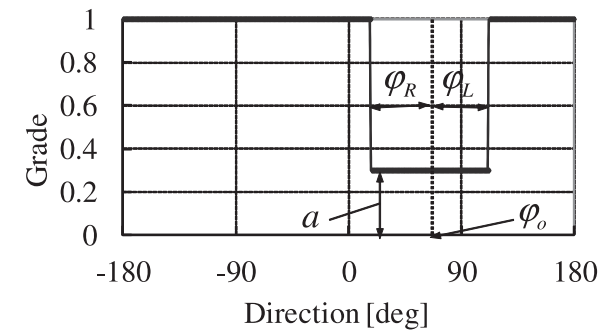

Fig. 8 Example of PMF $\mu_{o}^{n}$

$$
\begin{gathered}
\varphi_{\text {out }}=\arg \max \left(\mu_{\text {mix }}\right) \\
v_{\text {out }}^{\prime}=\mu_{\text {mix }}\left(\varphi_{\text {out }}\right) \cdot v_{\max } \\
v_{\text {out }}=v_{\text {out }}^{\prime}\left(1-\frac{1}{1+\exp \left(-\gamma\left(\left|\varphi_{\text {out }}\right| / 90-0.5\right)\right)}\right)
\end{gathered}
$$

式（13）は回転成分を優先するため, 出力制限を行うシグモイ ド関数である $[17]$. 設計パラメータ $\gamma$ は，文献 [17] に基づき $\gamma=25$ とした，最後に，角速度 $\omega_{\text {out }}$ は次式で決定する.

$$
\omega_{\text {out }}=\min \left(\varphi_{\text {out }}, \omega_{\max }\right)
$$

\section{4. 数值シミュレーション}

\section{1 シミュレーション条件}

提案する行動制御手法の有効性を検証するため，車いすを長さ $1.05[\mathrm{~m}]$, 幅 $0.65[\mathrm{~m}]$ の長方形としてモデル化し，幅 $2.0[\mathrm{~m}]$ の 通路を左折する数值シミュレーションを行った。 ここで, デバイ スからの入力は $0.5[\mathrm{~s}]$ 間隔でなされるが, 車いすの制御は LRF の動作周波数に合わせ， $0.1[\mathrm{~s}]$ 間隔で行う. 車いすは, Fig. 9 


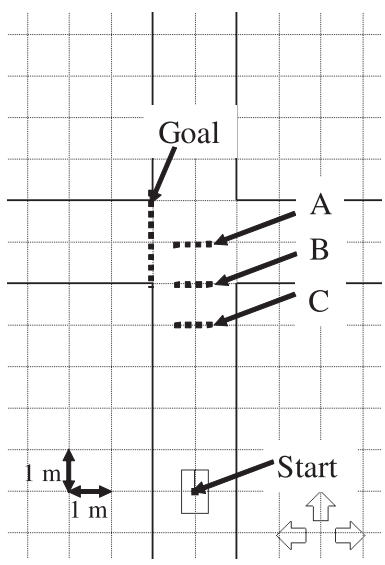

Fig. 9 Simulation environment for direction change

Table 1 Comparison of the methods

\begin{tabular}{lcll}
\hline Method & $\begin{array}{c}\text { Control of } \\
\text { angular velocity }\end{array}$ & $\begin{array}{l}\text { Target } \\
\text { direction }\end{array}$ & Deceleration \\
\hline Method 1 & $\times$ & Fixed & None \\
Method 2 & $\times$ & Fixed & uniformly $0.25[\mathrm{~m} / \mathrm{s}]$ \\
Method 3 & $\bigcirc$ & Fixed & uniformly $0.25[\mathrm{~m} / \mathrm{s}]$ \\
Method 4 & $\bigcirc$ & Corridor & uniformly $0.25[\mathrm{~m} / \mathrm{s}]$ \\
Proposed & $\bigcirc$ & Corridor & Dynamically \\
\hline
\end{tabular}

に示す, スタート地点 $(x, y)=(0.0[\mathrm{~m}] 0.0[\mathrm{~m}])$ から初速度 $0.0[\mathrm{~m} / \mathrm{s}]$ で移動を始めたあと， A， B，Cのいずれかの地点か ら左折を開始する。これは, どの地点から左折を始めるかあら かじめ分からないためである。このとき車いすに与える入力は, 自動で, スタートから $\mathrm{A}, \mathrm{B}, \mathrm{C}$ の各地点までは「前」, 左折 開始後, 車いすのヨー角が $70[\mathrm{deg}]$ を超えるまで「左」, その後 ヨー角が $70[\mathrm{deg}]$ から $110[\mathrm{deg}]$ の間は「前」を与えた。また, もし車いすのヨー角が左折後 $110[\mathrm{deg}]$ を超えた場合は「右」の 入力を与えた. ヨー角は初め $0[\mathrm{deg}]$ である. 左折の成否は, 車 いすの中心が Fig. 9 に示すゴールの線を超えたかどうかで判定 する. また，設計パラメータ $d_{t h}=0.3[\mathrm{~m}]$ とした，本研究で は, 以降, 断りのない限り, 以上のパラメー夕を用いて数值シ ミュレーションと実験を行う. 具体的には Table 1 の四つの手 法と提案手法で挙動を調査し, 提案手法の有効性を検証する.

\section{2 シミュレーション結果}

Fig. 10 (a) に手法 1, Fig. 10 (b) に手法 2, つまり十字路手 前で減速して移動した場合の車いすの軌跡を示す. 図中の車い すは $2[\mathrm{~s}]$ ごとにプロットされている.両シミュレーションとも に同じタイミングで入力を開始しているが, 手法 1 では, 入力 が間に合わず十字路を通過してしまい, 左折を行えていないが, 手法 2 では, 通路を検出し, 十字路手前で減速を行うことで, 搭乗者の入力を待つことができたため, 左折に成功しているこ とが分かる。 また, Table 2 に手法 1 , Table 3 に手法 2 に扔 ける全シミュレーション結果を示す，表に扔ける「○」はヨー 角が $110[\mathrm{deg}]$ を超えることなく左折に成功，「○」はヨー角が 1 回以上 $110[\mathrm{deg}]$ を超えたが左折に成功,「メ」は左折に失敗 したことを示す. Table 2 と Table 3 の比較から, 減速を行う ことで左折に成功しているケースが増加しており, 十字路手前 での減速により，右左折時の移動性能が向上寸ることが分かる，

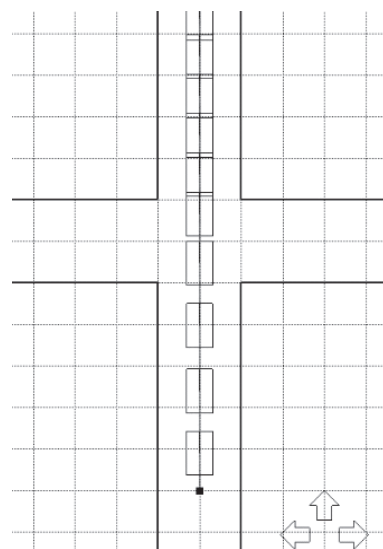

(a) Method 1

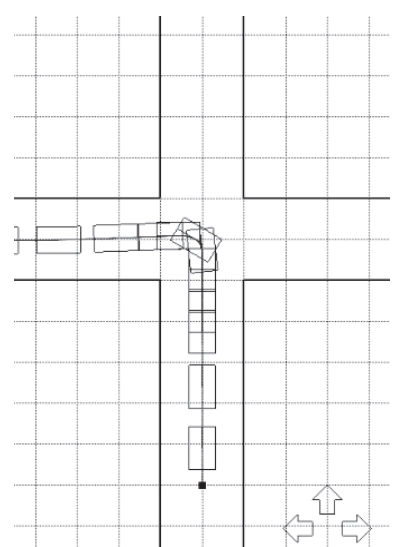

(b) Method 2
Fig. 10 Trajectory of wheelchair

(From position A, Target direction $22.5[\mathrm{deg}]$ )

Table 2 Simulation result with method 1

\begin{tabular}{cccc}
\hline Target & \multicolumn{4}{c}{ Starting Position $(x[\mathrm{~m}], y[\mathrm{~m}])$} \\
direction $[\mathrm{deg}]$ & $\mathrm{A}(0.0,6.0)$ & $\mathrm{B}(0.0,5.0)$ & $\mathrm{C}(0.0,4.0)$ \\
\hline 22.5 & $\times$ & $\bigcirc$ & $\bigcirc$ \\
45.0 & $\triangle$ & $\bigcirc$ & $\bigcirc$ \\
90.0 & $\bigcirc$ & $\times$ & $\times$ \\
\hline
\end{tabular}

Table 3 Simulation result with method 2

\begin{tabular}{cccc}
\hline Target & \multicolumn{4}{c}{ Starting Position $(x[\mathrm{~m}], y[\mathrm{~m}])$} \\
direction $[\mathrm{deg}]$ & $\mathrm{A}(0.0,6.0)$ & $\mathrm{B}(0.0,5.0)$ & $\mathrm{C}(0.0,4.0)$ \\
\hline 22.5 & $\bigcirc$ & $\bigcirc$ & $\bigcirc$ \\
45.0 & $\triangle$ & $\bigcirc$ & $\times$ \\
90.0 & $\times$ & $\times$ & $\times$ \\
\hline
\end{tabular}

Table 4 Simulation result with method 3

\begin{tabular}{cccc}
\hline Target & \multicolumn{3}{c}{ Starting Position $(x[\mathrm{~m}], y[\mathrm{~m}])$} \\
direction $[\mathrm{deg}]$ & A $(0.0,6.0)$ & $\mathrm{B}(0.0,5.0)$ & $\mathrm{C}(0.0,4.0)$ \\
\hline 22.5 & $\bigcirc$ & $\bigcirc$ & $\bigcirc$ \\
45.0 & $\bigcirc$ & $\bigcirc$ & $\times$ \\
90.0 & $\triangle$ & $\times$ & $\times$ \\
\hline
\end{tabular}

Fig. 11 (a) に手法 2, Fig. 11 (b) に手法 3,つまり減速に加え て回転時の角速度の調整を行った場合の車いすの軌跡, Fig. 12 に両シミュレーションに扔ける車いすのヨー角の時刻歴を示す. これらの結果より, 両者ともに左折に成功しているが, 手法 2 に比べ, 角速度の調整を行う手法 3 のほうが, ヨー角の履歴は 振動的になって扮らず，角速度調整の有効性が確認できる。 ま た, Table 4 に手法 3 に扔ける全シミュレーション結果を示 す. Table 3 と Table 4 の比較より, 角速度の調整を行うこと で, 急旋回を要する場合の右左折の質が向上していることが分 かる，これは，目標方向が大きい場合，大きな角速度を出力す るように制御がなされるが, 手法 3 では, 角速度の調整を行う ことにより, 入力を待ち, 先に進行するかどうか判断する時間 が与えられたためであると考えられる。

最後に, Fig. 13 に, Fig. 11 と同様の位置から左折した場合 に打ける, 手法 4 と提案手法の軌跡を示す. また, Table 5 に 手法 3, Table 6 に手法 4 と提案手法に扔ける, 左折開始から 終了までに要した時間を示す. Fig. 11 と Fig. 13 の比較から, 


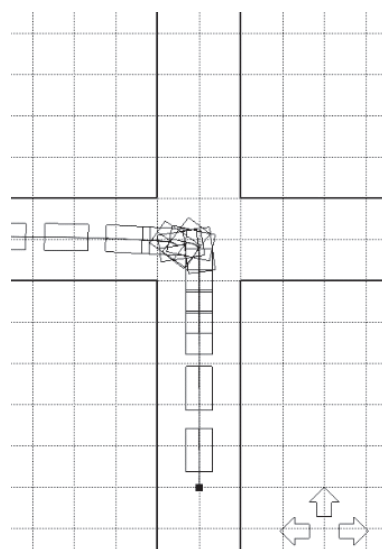

(a) Method 2

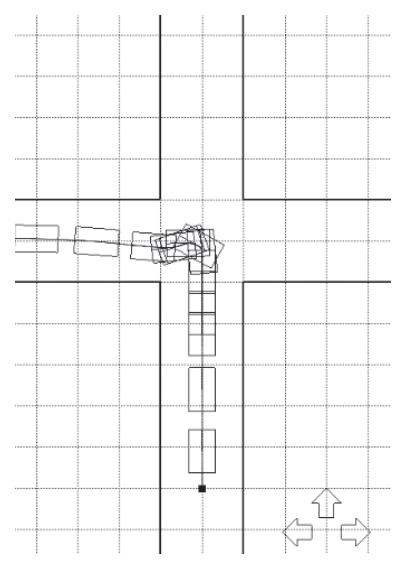

(b) Method 3
Fig. 11 Trajectory of wheelchair (From position A, Target direction $45.0[\mathrm{deg}]$ )

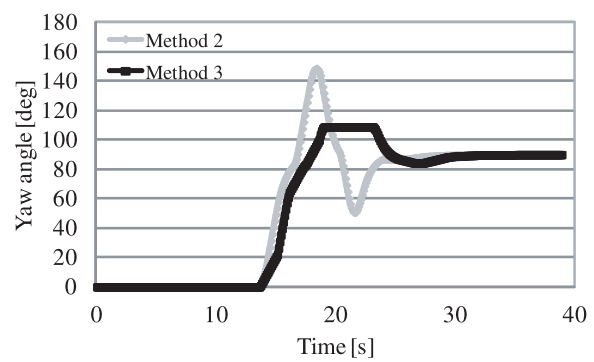

Fig. 12 Time history of yaw angle

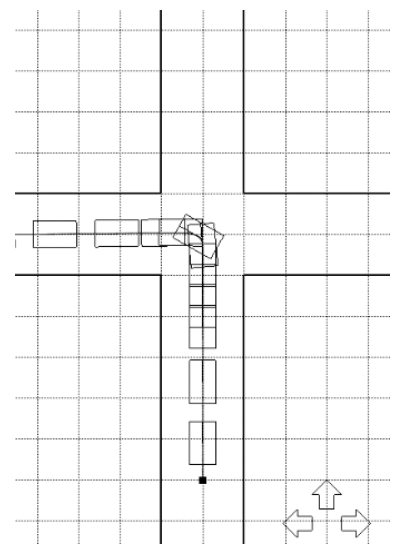

(a) Method 4

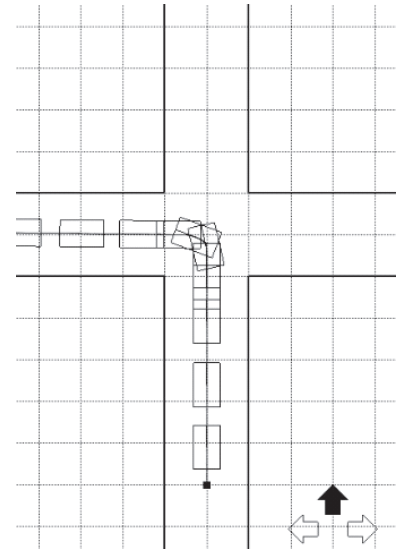

(b) Proposed Method
Fig. 13 Trajectory of wheelchair (From position A)

目標方向を固定せず，通路方向に設定することで，右左折がよ り滑らかに行えていることが分かる. さらに, Table 5 と Table 6 から，目標方向を動的に調整し，車いすを通路方向へ誘導し た結果，車いすの左折終了までの時間が，目標方向を固定した 場合と比較し，短くなっていることが分かる．特に C 地点から の移動に扔いて $2[\mathrm{~s}]$ 以上早く移動が終了している。したがって, 目標方向を通路方向にすることで，様々な位置からの右左折に 対し, 効率的な移動が実現できると言える. また, 手法 4 と提案 手法の差は, 通路検出時に一定值まで減速させるか, その位置 関係に応じて動的に速度調整を行うかであるが, 今回のシミュ
Table 5 Traveling time for turning to left

\begin{tabular}{cccc}
\hline Target & \multicolumn{3}{c}{ Starting Position $(x[\mathrm{~m}], y[\mathrm{~m}])$} \\
direction $[\mathrm{deg}]$ & A $(0.0,6.0)$ & $\mathrm{B}(0.0,5.0)$ & $\mathrm{C}(0.0,4.0)$ \\
\hline 22.5 & $6.8[\mathrm{~s}]$ & $7.7[\mathrm{~s}]$ & $13.8[\mathrm{~s}]$ \\
45.0 & $11.8[\mathrm{~s}]$ & $18.5[\mathrm{~s}]$ & $\times$ \\
90.0 & $15.5[\mathrm{~s}]$ & $\times$ & $\times$
\end{tabular}

Table 6 Traveling time for turning to left

\begin{tabular}{cccc}
\hline Target & \multicolumn{3}{c}{ Starting Position $(x[\mathrm{~m}], y[\mathrm{~m}])$} \\
direction $[\mathrm{deg}]$ & A $(0.0,6.0)$ & $\mathrm{B}(0.0,5.0)$ & $\mathrm{C}(0.0,4.0)$ \\
\hline Method 4 & $6.5[\mathrm{~s}]$ & $7.7[\mathrm{~s}]$ & $11.4[\mathrm{~s}]$ \\
Proposed method & $6.2[\mathrm{~s}]$ & $7.3[\mathrm{~s}]$ & $9.9[\mathrm{~s}]$ \\
\hline
\end{tabular}

レーションにおいては，軌跡に大きな差は見られなかった。し かしながら, Table 6 から, 通路から遠い位置で左折を始める ほど，提案手法のほうが移動時間が短くなることが分かる。こ れは手法 4 では, 通路が検出されている限り, 速度が一定值に 保たれるが, 提案手法では, 通路の位置に応じて動的に速度が 調整されるため, $0.25[\mathrm{~m} / \mathrm{s}]$ 以下まで減速している時間が短い ためである. 以上より, 提案する制御システムは, 操作性の低 いデバイスを利用する車いすの移動性能を向上させると言える.

\section{5. 実}

\section{験}

\section{1 実験条件}

提案手法の実環境に拄ける有効性を検証するため, Fig. 14 に示す, 長さ $1.05[\mathrm{~m}]$, 幅 $0.65[\mathrm{~m}]$ のヤマハ発動機製車いす電 動化ユニット JWX-1 を搭載した車いすを利用した実験を行っ た。車いすには LRF として, 前方約 $0.40[\mathrm{~m}]$, 床面から高さ $0.10[\mathrm{~m}]$ の位置に北陽電機製測域センサ URG-04LX-UG01 が 設置されている. LRF は数值シミュレーションとは異なり, 車 いすの中心に設置されていないが，幾何計算を行い，車いす中 心から見たデー夕に変換したものを制御では利用する. 電動化 ユニットの特徵から, 両輪の速度を指令值として与えることが できないため, 最大速度を JWX-1 で与えることのできる最小 值である $0.47[\mathrm{~m} / \mathrm{s}]$ と固定し, 提案手法による速度の調節は行 わない，また，車いすには，パソコンからキーボードを用いて， 疑似的に $2.0[\mathrm{~Hz}]$ の動作周波数で「前」,「右」,「左」の入力を 与えた，車いすは LRF のデータ取得周期に合わせて $0.1[\mathrm{~s}]$ 間 隔で制御を行う。また，障害物とのマージン $d_{t h}$ を $0.25[\mathrm{~m}]$ と した。

実験は, 特に行う頻度が高いと考えられる, 右左折（ここで は右折）および障害物回避の二つの車いすの操作を対象に行い, 提案手法の有効性を検証する，比較手法としては，「前」で前 進,「右」で時計回りにその場旋回，「左」で反時計回りにその 場旋回，の三つの動作のみを行うことができる車いすを対象と した，また，実験における車いすの操作は，提案手法について 事前知識のない, 本大学の学生 10 名（男： 7 名, 女： 3 名）が 行った，それから，被験者は「前」「右」，「左」の各方向に入 力する際，キーボードを押し続けることで入力を行うが，先述 したように，デバイスの動作周波数を疑似的に $2.0[\mathrm{~Hz}]$ にして いるため，機械側には入力が $0.5[\mathrm{~s}]$ 間隔で変化して見える.

右折の実験では, Fig. 15 および Fig. 16 に示すような環境 

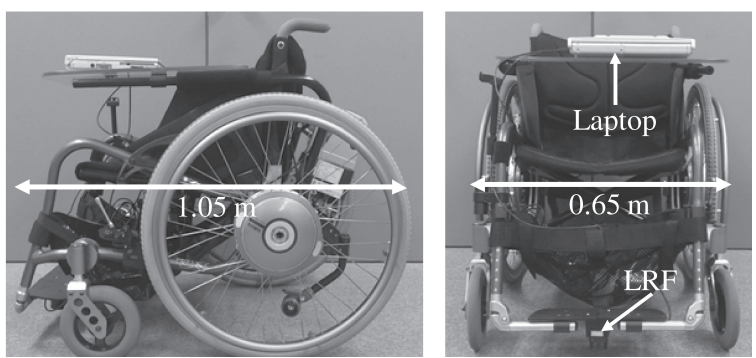

Fig. 14 Overview of wheelchair

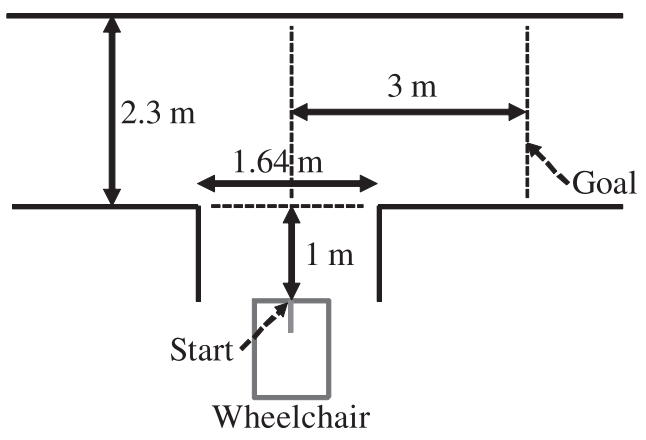

Fig. 15 Experimental condition for direction change

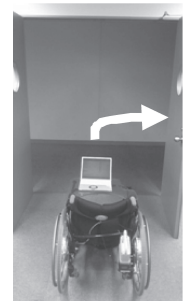

(a) Back

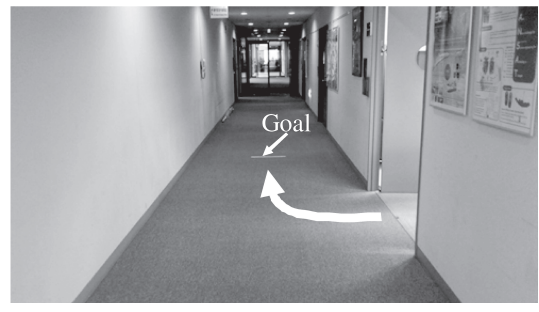

(b) Lateral
Fig. 16 Experimental environment for direction change

において, スタート地点からゴール地点に向けて, 比較手法, 提 案手法の両方で，右折を行う実験を行った。その際，被験者に は，スタート後，ゴール地点の線を車いすが完全に通過するま で操作を行い，通過し終わったと判断したら操作を止めるよう 指示し，右折にかかった時間および左右方向への搭乗者の入力 回数を比較する.

障害物回避実験では，Fig. 17 およびFig. 18 に示すような 環境において, 幅 $0.5[\mathrm{~m}]$, 長さ $0.3[\mathrm{~m}]$ の障害物を, 車いすを 操作し, 回避しながら前進する実験を行った。 また提案手法が, 設定したマージンを維持して障害物を回避できるか確認するた め, Fig. 19 に示すように，障害物周囲にマージンを視覚的に 示すための線を引いた。車いすは，そのまま直進を行った場合， 障害物に衝突するような位置から移動を開始する。また，車い すの操作は, 右折の実験と同様, ゴール地点の線を車いすが完 全に通過するまで行い，障害物回避にかかった時間および左右 方向への搭乗者の入力回数を比較する. 本実験では, 提案手法 がどのように搭乗者をアシストするかについて, 被験者には事 前に説明を行わず操作を行ってもらった. また, 全試行は, 比 較手法で車いすを操作後, 提案手法で操作をするという順番で 行った。

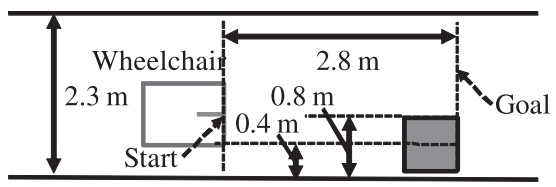

Fig. 17 Experimental condition for obstacle avoidance

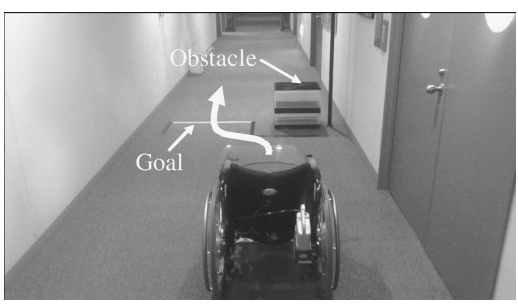

Fig. 18 Experimental environment for obstacle avoidance

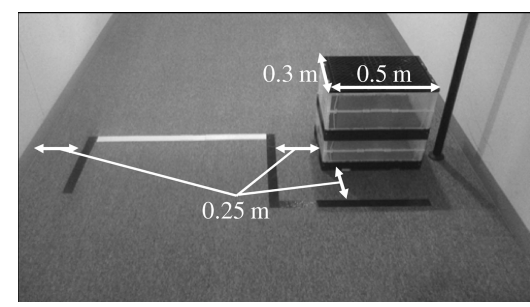

Fig. 19 Experimental environment around obstacle

\section{2 実験結果}

\section{2 .1 右折}

比較手法で移動した場合と提案手法で移動した場合の右折の 様子を動画像として撮影した. Fig. 20 に 1 人の被験者の移動 の様子, Fig. 21, Fig. 22 にそのとき搭乗者が与えた入力の履 歴を示す. 図中の 0 から 3 までの数字はそれぞれ, 「0: 入力な し」,「1: 前」,「2: 左」,「3: 右」に対応する.

Fig. 20 (a), Fig. 20 (b) の結果を比較すると，提案手法のほう が比較手法より短時間で移動が終わっていることが分かる。こ れは提案手法では停止することなく, 滑らかに右折できたのに 対して, 比較手法では車いすの進行方向を変えるために, 一度 停止し, 旋回する動作を, 2 回行う必要があったためである. 実 際に, Fig. 21 およびFig. 22 の入力の時刻歴から, 提案手法で は, 右方向への入力は $5[\mathrm{~s}]$ から 1 回, $4[\mathrm{~s}]$ 程度行っただけと なっているが, 比較手法では, 2 回右方向への入力を行ってい ることが確認できる.

また, Table 7 に各被験者が実験中, 右もしくは左に入力し た回数, Fig. 23 に移動に要した時間を示す. 提案手法の方が 比較手法に比べ，入力回数が少なく移動を行えており，ほとん どの被験者は提案手法において 1 回の右方向の入力で移動を終 えている.これから, 提案手法は比較手法に比べ, より少ない 入力で右左折を行うことができると考えられる。そして，いず れの被験者も比較手法で移動する場合より，提案手法で移動し た場合の方が，入力を終えるまでの時間が短くなっており，移 動時間も短縮できている，以上の結果より，実環境においても 提案手法は, 少ない入力で効率的な右折を, 操作性の低いデバ イスを用いる車いすで実現できることが分かった。 

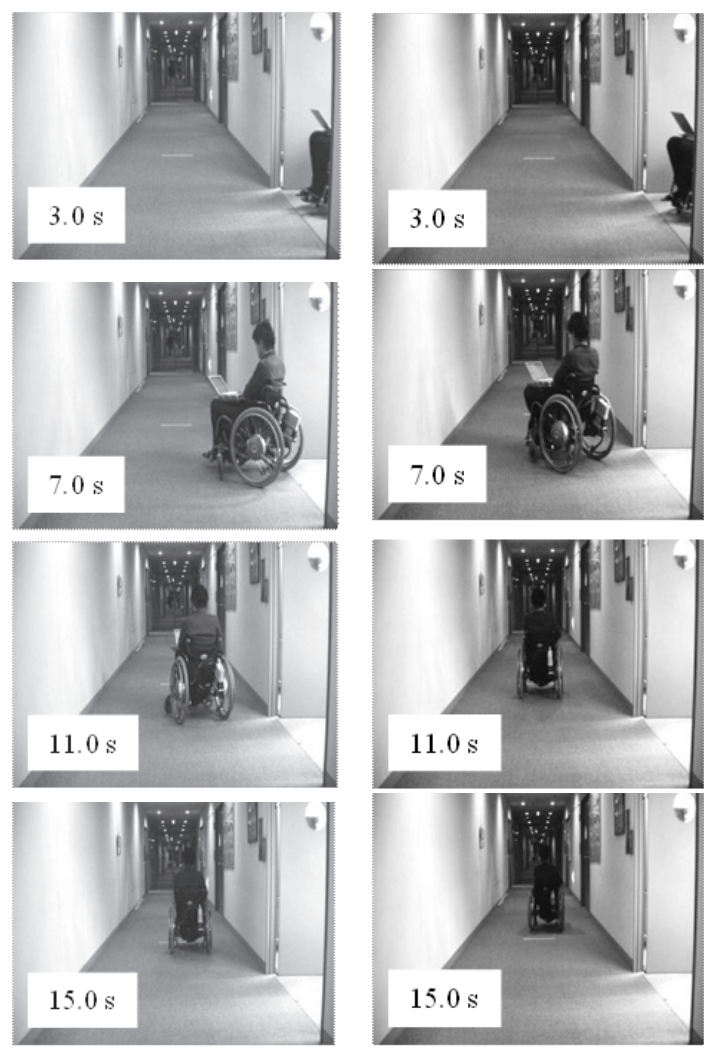

(a) Comparative

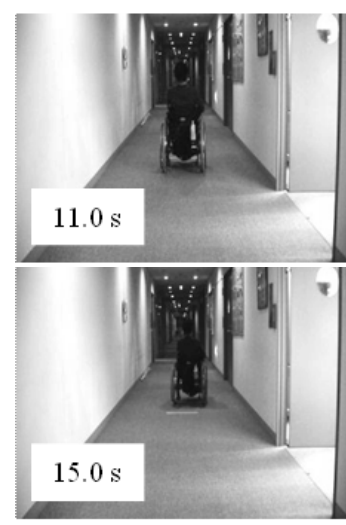

(b) Proposed

Fig. 20 Experimental result of direction change

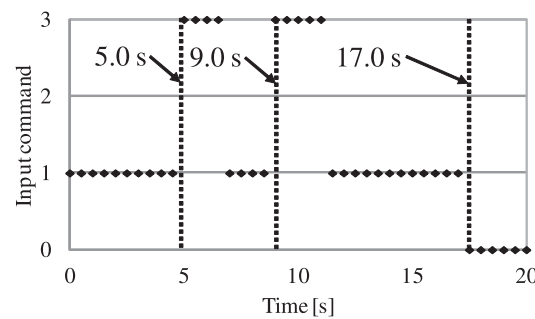

Fig. 21 The input commands with comparative method in direction change experiment

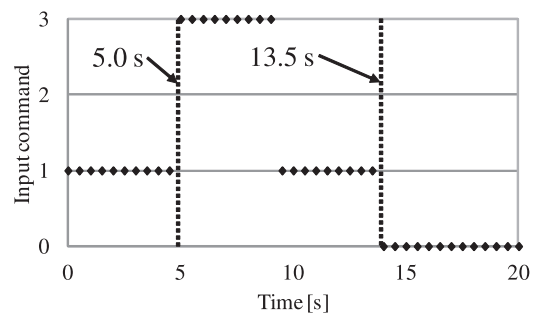

Fig. 22 The input commands with proposed method in direction change experiment

\section{2 .2 障害物回避}

前項の実験と同様に，比較手法で移動した場合と，提案手法 で移動した場合の障害物回避の様子を動画像として撮影した。 Fig. 24 に 1 人の被験者の移動の様子, Fig. 25, Fig. 26 にそ のとき搭乗者が与えた入力の履歴を示す.

Fig. 24 の左右を比較すると, 右折の実験と同様, 提案手法の

Table 7 Input times to right or left while changing direction

\begin{tabular}{ccccccccccc}
\hline Method & \multicolumn{11}{c}{ Subject } \\
& A & B & C & D & E & F & G & H & I & J \\
\hline Comparative & 2 & 2 & 4 & 4 & 2 & 3 & 2 & 3 & 4 & 2 \\
Proposed & 1 & 1 & 1 & 1 & 1 & 1 & 1 & 2 & 2 & 1 \\
\hline
\end{tabular}

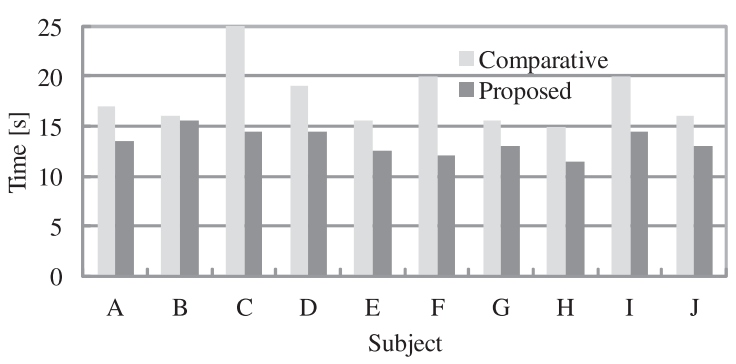

Fig. 23 Traveling time till finish turning to right
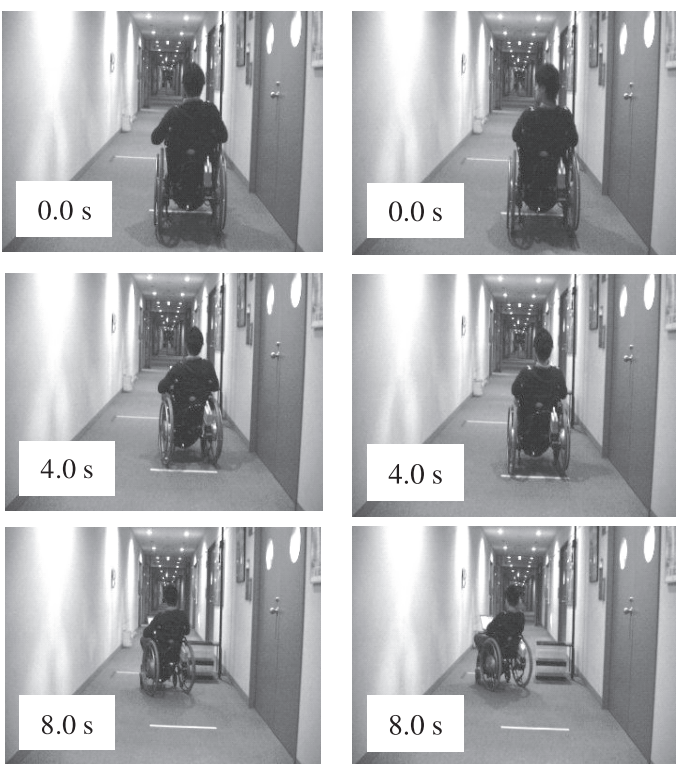

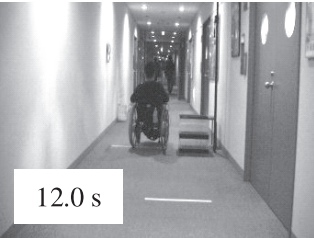

(a) Comparative
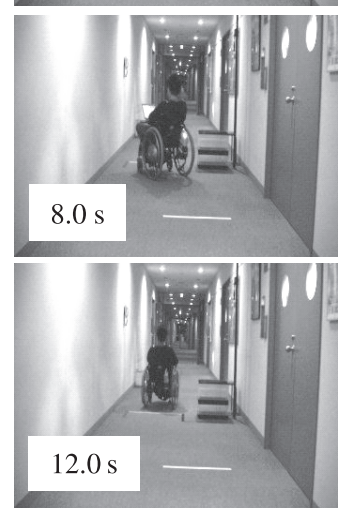

(b) Proposed
Fig. 24 Experimental result of obstacle avoidance

ほうが比較手法より短時間で移動が終わっていることが分かる これは提案手法では障害物回避を自動的に行ったことによって， 滑らかに移動することができたが，比較手法では 3 回ほどその 場旋回を行い，小刻みに進行方向を調整する必要があったため である.これは Fig. 25, Fig. 26 に示した搭乗者の入力からも確 認でき, 左右方向への入力回数は提案手法のほうが少なく, 入 力を終えるまでの時間も短い.

また, Table 8 に各被験者が実験中, 右もしくは左に入力し た回数，Fig. 27 に障害物回避を終了するまでに要した時間を 示す.ここで, Table 8 の「×」は障害物に衝突し, 回避に失 敗したことを表している。Table 8 から，多くの被験者が移動 


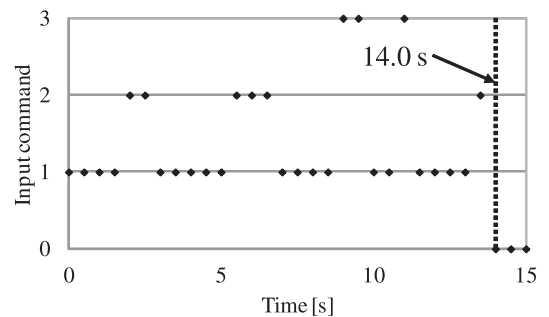

Fig. 25 The input commands with comparative method in obstacle avoidance experiment

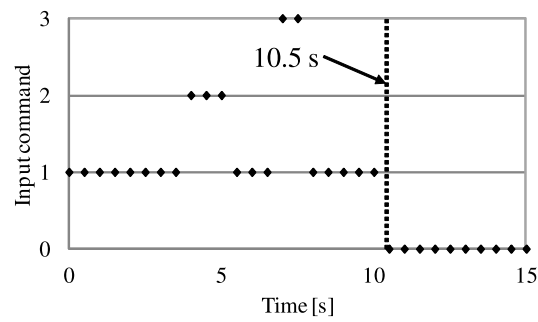

Fig. 26 The input commands with proposed method in obstacle avoidance experiment

Table 8 Input times to right or left while avoiding obstacle

\begin{tabular}{ccccccccccc}
\hline Method & \multicolumn{11}{c}{ Subject } \\
& A & B & C & D & E & F & G & H & I & J \\
\hline Comparative & 5 & 4 & $\times$ & 2 & 3 & 3 & 3 & 3 & 3 & 5 \\
Proposed & 2 & 2 & 0 & 2 & 1 & 2 & 2 & 2 & 3 & 3 \\
\hline
\end{tabular}

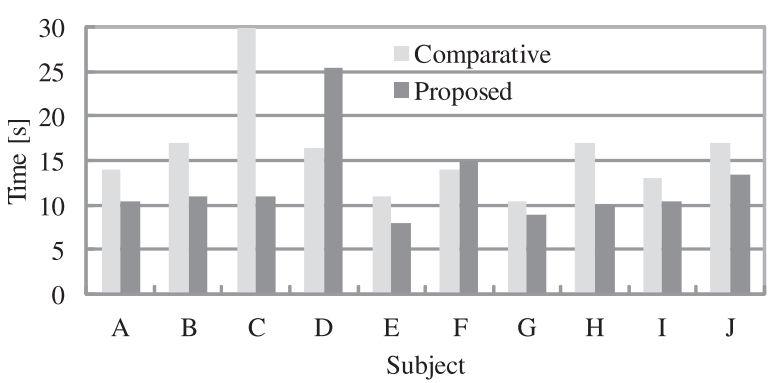

Fig. 27 Traveling time till finish avoiding obstacle

に際し，比較手法に比べ, 左右方向への入力回数を減らすこと ができていることが分かる. 特に被験者 $\mathrm{C}$ は左右方向に 1 回も 入力することなく, 障害物回避が行えている. これは, 提案手 法が自動的に搭乗者の目標を判断し，移動を行ったことによっ て, 比較手法に比へ，細かな操作が不要になったことが主な理 由として考えられる. さらに, Fig. 27 をみると, 提案手法では 比較手法のように，その場旋回等を行う必要がなかったことに より，多くの被験者が移動時間を短縮できていることが確認で きる，被験者 $\mathrm{D}$ 抢よび被験者 $\mathrm{F}$ は，提案手法を適用したこと で移動時間が増加しているが, これは, 提案手法について事前 知識がなかったことや，操作に慣れていなかったことが主な要 因として考えられる，実際，被験者 Cのように，今回の上うな 障害物との位置関係では, 提案手法は左右方向への入力を行わ ずとも，前方向への入力のみを与えることで，車いすが自動的 に障害物を回避し，前進することができ，この特徴をあらかじ め知っていれば，効率的に移動が行えたと考えられる。

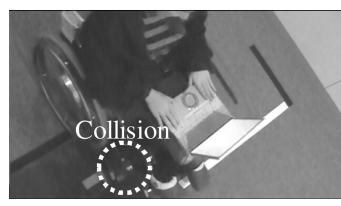

(a) Comparative

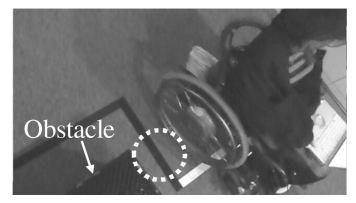

(b) Proposed
Fig. 28 The input commands with conventional method 2

最後に，いずれの試行に扔いても提案手法は，障害物やその 周囲の壁などに衝突することなく, Fig. 19 に示したマージン内 に車いすが侵入することはなかった，また，何人かの被験者は， 比較手法では，Fig. 28 (a)のように，操作ミスや判断ミスによ り，障害物に衝突してしまったり，障害物に非常に近づいてし まったりする場面が見受けられたが，同じ被験者でも，提案手法 を適用することで，Fig. 28 (b) に示すように，障害物からマー ジンの距離を保ちながら移動が可能になったことを確認した。

以上より, 提案手法は実環境に扔いても, 搭乗者の安全を確 保しながら, 少ない入力で効率的な障害物回避を, 操作性の低 いデバイスを用いる車いすにおいて実現できることが分かった。

\section{6. 結言}

本研究では, 入力方向が少ない, 動作周波数が低いといった 特徵を持つ, 操作性の低いデバイスを利用して操作する電動車 いすの安全で効率的な移動の実現を目的とした，デバイスの操 作性の低さを補い，安全で効率的な移動を実現するアシストを 行うため, 搭乗者の操作入力と車いすに取り付けられた外界セ ンサから得られる環境情報を同時に考慮し，搭乗者の行動意図 を推定した，そして推定した行動意図や環境に応じた速度指令 を決定し、移動を行う，車いすの行動制御手法を提案した。ま た，アシストシステムの具体的な設計法として，ファジイポテン シャル法に基づく行動制御系の設計例を提示した。ささらに, 環 境認識のため, レーザレンジファインダを利用した，簡易的な 通路検出アルゴリズムも提案した，そして，数值シミュレーショ ンと市販の車いすを利用した実機実験を通じ, 提案手法がデバ イスの操作性の低さを補い，それを利用する車いすの，安全性 と移動の効率性を向上させることを示した.

今後の課題としては, 実物のブレインマシンインタフェース を利用した提案手法の有効性の検証，ノイズや入力ミスなどに 起因する, 操作入力の不確かさへの対応, 行動制御系では今回 考慮していない, 車い寸移動時に発生する前後㧍よび左右方向 の振動低減による乗り心地の向上などが挙げられる.

謝 辞 本研究の一部は文部科学省グローバル COE プログ ラム「環境共生・安全システムデザインの先導拠点」によるも のであることを記し，謝意を表す。

\section{参 考 文 献}

[1] ハンドル形電動車いすの安全性調査報告書. 独立行政法人製品評価技 術基盤機構, 2008.

[2 2 R. Simpson, E. LoPresti and R. Cooper: "How many people would benefit from a smart wheelchair?," Journal of Rehabilitation Research and Development, vol.45, no.1, pp.53-72, 2008.

[ 3 ] S. Levine, D. Bell, L. Jaros, R. Simpson, Y. Koren and J. Borenstein: "The NavChair Assistive Wheelchair Navigation 
System," IEEE Transactions on Rehabilitation Engineering, vol.7, no.4, pp.443-451, 1999.

[ 4 ] E. Deemester, A. Huntemann, D. Vanhooydonck, G. Vanacker, H.V. Brussel and M. Nuttin: "User-adapted plan recognition and user-adapted shared control: A Bayesian approach to semiautonomous wheelchair driving," Autonomous Robots, vol.24, pp.192-211, 2008.

[5] S. Katsura and K. Ohnishi: "Semiautonomous Wheelchair Based on Quarry of Environmental Information," IEEE Transactions on Industrial Electronics, vol.53, no.4, pp.1373-1382, 2006.

[6] E. Prassler, J. Scholz and P. Fiorini: "A Robotic Wheelchair for Crowded Public Environments," IEEE Robotics and Automation Magazine, vol.8, pp.38-45, 2001.

[7] R. Simpson and S. Levine: "Voice Control of a Powered Wheelchair," IEEE Transactions on Neural Systems and Rehabilitation Engineering, vol.10, no.2, pp.122-125, 2002.

[8] T. Saitoh, N. Takahashi and R. Konishi: "Development of an Intelligent Wheelchair with Visual Oral Motion," IEEE International Conference on Robot and Human Interactive Communication, pp.145-150, 2007.

[ 9 ] I. Iturrate, J. Antelis, A. Kubler and J. Minguez: "A Noninvasive Brain-Actuated Wheelchair Based on a P300 Neurophysiological Protocol and Automated Navigation," IEEE Transactions on Robotics, vol.25, no.3, pp.614-627, 2009
[10] 青木治雄, 田中拓哉, 大竹博, 田中一男：“脳波を利用した運動イメー ジの識別と外界センサを利用した電動車椅子制御”，日本機械学会口 ボティクス・メカトロニクス講演会予稿集，2011.

[11] 足立佳久, 中西知, 久野義徳, 島田伸敬, 白井良明: “顔の視覚情報処理を 用いた知的車椅子”, 日本ロボット学会誌, vol.17, no.3, pp.423-431, 1999.

[12] G. Vanacker, J. Millan, E. Lew, P. Ferrez, F. Moles, J. Phillips, H. Brussel and M. Nuttin: "Context-Based Filtering for Assisted Brain-Actuated Wheelchair Driving," Conputational Intelligence and Neuroscience, vol.2007, pp.1-12, 2007.

[13] J. Millan, F. Renkens, J. Mourino and W. Gerstner: "Noninvasive Brain-Actuated Control of a Mobile Robot by Human EEG," IEEE Transactions on Biomedical Engineering, vol.51, no.6, pp.1026-1033, 2004.

[14] J. Laarson, M. Broxvall and A. Saffiotti: "Laser Based Corridor Detection for Reactive Navigation," Industrial Robot, vol.35, no.1, pp.69-79, 2008.

[15] 三浦曜, 望月一正：CAD · CG 技術者のための実践 NURBS. 工業 調査会, 2004

[16] ISO-2631-1:1997, Mechanical vibration and shock - Evaluation of human exposure to whole-body vibration- Part 1 . General requirements, 1997.

[17] 津崎亮一, 吉田和夫: “ファジィポテンシャル法に基づく全方位視覚を 用いた自律移動ロボットの行動制御”, 日本ロボット学会誌, vol.21, no.6, pp.656-662, 2003.

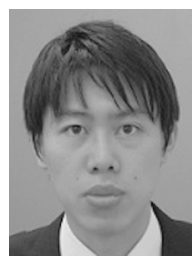

\section{石原 悠（Yu Ishihara）}

2010 年慶應義塾大学理工学部システムデザイン工 学科卒業. 2012 年慶應義塾大学大学院理工学研究 科前期博士課程修了。（日本ロボット学会学生会員）

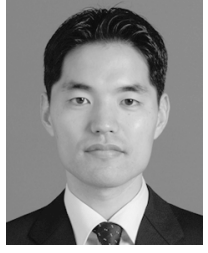

などの会員
高橋正樹（Masaki Takahashi）

2004 年慶應義塾大学大学院理工学研究科後期博士 課程修了. 博士 (工学). 主に知的制御, ロボット 工学, 宇宙工学, ソフトコンピューティング, 人工 知能の研究に従事. 現在, 慶應義塾大学理工学部シ ステムデザイン工学科准教授. IEEE，AIAA，日 本機械学会, 日本航空宇宙学会, 計測自動制御学会

(日本ロボット学会正会員) 